\author{
선인장색소 및 유산나트륨이 저 아질산염 소시지에 미치는 효과 \\ 강종옥 · 이상길 \\ 단국대학교 동물자원학과
}

\title{
Effects of Opuntia ficus-indica Pigment and Sodium Lactate on Nitrite-reduced Sausages
}

\author{
Jong-Ok Kang and Sang-Gil Lee \\ Department of Animal Resources and Science, Dankook University, Cheonan, 330-714, Korea
}

\begin{abstract}
This study was carried out to investigate the effect of Opuntia ficus indica (prickly pear) pigment and sodium lactate on nitrite-reduced sausages. The $\mathrm{a}^{*}$ value, total bacterial counts, $\mathrm{pH}$, water holding capacity, texture analysis, sensory evaluation of sausages, body weight gain and blood glucose of rat for 4 weeks were not significantly different between the control and treatments. However, 2-thiobarbituric acid (TBA) values and cholesterol (total, LDL, HDL) and neutral fat of blood were significantly different between the control and treatments $(\mathrm{P}<0.05)$. TBA value was lower in control and cholesterol and neutral fat were lower in treatments. Among the treatments T2 $(30 \mathrm{ppm}$ of nitrite $+2 \%$ of sodium lactate $+0.2 \%$ Opuntia ficus indica pigment) was the most effective. In conclusions, this study suggested that T2 can reduce adding level of nitrite from $100 \mathrm{ppm}$ to $30 \mathrm{ppm}$ without any changes in color, shelf life and flavor of sausages. In addition, it had the effect on the reduction of cholesterol and neutral fat in blood.
\end{abstract}

(Key words : Opuntia ficus indica pigment, Sodium lactate, Nitrite-reduced sausage)

\section{I. 서 론}

아질산염 $(\mathrm{K}$ 또는 $\mathrm{Na})$ 은 채소 및 타액, 생선 등 많은 식품에 함유되어 있다. 육제품에 통상 사용되는 아질산염은 육제품의 발색 및 항 미 생물 작용뿐만 아니라 항산화력, 보수력 및 풍 미 증진에도 영향을 준다 (강과 이, 2003). 그러 나 아질산염은 체내에서 단백질을 구성하고 있 는 아민류와 아질산염의 아질산 (nitrous acid)의 반응으로 nitrosamine이라는 발암물질의 생성 가능성과 혈액의 hemoglobin을 met-hemoglobin 으로 산화시켜 산소운반 능력을 저하 시킨다 (Massey 등, 1978).
최근 소비자로부터 아질산염 과민반응의 문 제를 해결하기 위한 다양한 연구가 진행되고 있는데, 이러한 연구는 크게 천연소재를 이용 하여 아질산염을 대체하는 방법과 저감화 (부분 대체) 방법으로 나눌 수 있다. 천연 소재로서 첫째, 색소로는 흑미 (강 등, 2001), 레드비트 (강과 이, 2003), 홍국 (류 등, 2003), lac 색소 (국 등, 2003) 등이 있으며, 둘째, 항 미생물기 능으로는 유기산제인 구연산, 솔빈산, 초산, 젖 산(O’Boyle 등, 1990; Sofos 등, 1980) 등이 있 고, 천연 동물성 식이섬유인 키토산 등이 있다 (윤 등, 2001; Chin 등, 2006).

그러나 상기 제시된 연구 결과에 따르면 아

Corresponding author : Jong-Ok, Kang, Department of Animal Resources Science, Dankook University, Cheonan 330-714, Korea.

Tel : 82-41-550-3653, Fax: 82-41-550-3653, E-mail : jokang@dankook.ac.kr 
질산나트륨을 사용하지 않은 천연색소는 육제 품색상에 광택이 없어 좋지 않을 뿐만 아니라 (강과 이, 2003), 항 미생물제 사용 또한 1.5 3.5\% 사용 시 효과를 나타내는 것으로 보 고되고 있으나(Mass 등, 1989; Choi 등 2003), $3 \%$ 이상 사용 시에는 경제성과 관능적 특성에 비추어 사용량이 과다한 단점이 있다고 사료된 다. 또한 대부분의 연구결과는 발색 또는 저장 성을 동시에 향상시키지는 못하고 있는 실정이 다.

최근에 이러한 단점을 보완하기 위한 방법의 일환으로 야채추출물 중에 함유된 천연 유래의 아질산염과 환원성 세균을 이용하는 방법이 독 일에서 개발되어 그 소재가 수입되고 있다(총 판: 지오푸드택).

선인장 색소의 주성분은 베타레인 (betalain)으 로 적색의 베타시아닌과 황색의 베타잔틴으로 분류되는 천연 적색 색소로서, 노랑에서 진 보 라색까지 온도, 시간, $\mathrm{pH}$, 농도에 따라 다양한 색상의 분포를 보이며, 항생, 항균효과를 지니 고 있는 것으로 알려져 있다(최 등, 2002a; 최 등 2002b).

따라서 본 연구는 육제품 제조 시 소량의 아 질산나트륨과 유산나트륨, 천연 베타레인 성분 이 함유된 손바닥 선인장 색소를 사용하여 아 질산염을 최소화하면서 발색과 저장성을 동시 에 향상시킬 수 있는 방법을 개발하고 또한 손 바닥 선인장이 첨가된 소시지의 혈액특성을 검 토하기 위해 실시되었다.

\section{ㅍ. 재료 및 방법}

\section{1. 소시지 제조 및 배합}

원료육은 대전충남양돈협동조합에서 냉장 돈 육의 후지 (뒷다리) 및 등 지방을 구매하였으며, 사용 시까지 돈육은 냉장상태로, 지방은 냉동 상태로 보관 되었다. 선인장 색소는 선인장 열 매를 $-40^{\circ} \mathrm{C}$ 에서 동결 건조하여 powder로 된 것을 제주 선인장마을로부터 구입하였으며, 유 산나트륨은 (주)송광양행으로부터 구입하였다. 아질산나트륨은 $5 \%$ 의 아질산나트륨을 함유한 nitrite pickle salt(NPS)가 사용되었다. 소시지는 제조 시 NPS $0.2 \%$ (아질산나트름 $100 \mathrm{ppm}$ )만을 첨가한 것을 대조구로 하였으며, 처리구는 0.12\% (T1: 아질산나트륨 $60 \mathrm{ppm}), \quad 0.06 \%$ (T2: 아질산나트륨 $30 \mathrm{ppm}), 0 \%(\mathrm{~T} 3:$ 아질산나트륨 0 $\mathrm{ppm})$ 로 아질산나트륨을 감소시킨 반면, 저장성 및 발색보완을 위해서는 유산나트륨은 $1 \%(\mathrm{~T} 1)$, $2 \%(\mathrm{~T} 2), \quad 3 \%(\mathrm{~T} 3), \quad$ 선인장 추출 색소 (주로 betalain)는 $0.1 \%(\mathrm{~T} 1), 0.2 \%(\mathrm{~T} 2), 0.3 \%(\mathrm{~T} 3)$ 로 각 각 아질산염 감소량에 따라 농도를 증가시켜 사용되었다 (Table 1).

그 외 향신료로는 인산염 0.2 , 비타민 C 0.05 , Mace 0.05, Coriander 0.05, White pepper 0.2, 미 원 0.2, Ginger 0.03, Cardamom 0.03, 설탕 $0.5 \%$ 각각 동량 첨가하였다.

\section{2. 색도 측정}

시료를 절단하여 표면을 Chroma Meter (Model CR-200b, Minolta, Japan)로 C광원에서 명도 (lightness)를 나타내는 L*, 적색도 (redness) 를 나타내는 $\mathrm{a}^{*}$, 황색도 (yellowness)를 나타내는 $\mathrm{b}^{*}$ 값을 각각 측정하였다. 이때의 표준색판은 $\mathrm{L}=99.6, \mathrm{a}=0.3, \mathrm{~b}=1.7$ 인 calibration plate를 표준 으로 사용하였으며, 시료 6 부위를 7 반복 측정 하여 평균값을 구하였다.

\section{3. 산패도 측정}

소시지의 지방산패 정도를 평가하기 위한 TBARS (Thiobarbituric Acid Reactive Substances) 함량 분석은 돈육 $10 \mathrm{~g}$ 을 homogenizer에 $20 \%$ trichloroacetic acid(TCA)용액 $25 \mathrm{~mL}$ 를 첨가하 여 2분간 $14,000 \mathrm{rpm}$ 으로 균질화한 뒤, 현탁액 을 메스플라스크에 넣어 증류수로 $100 \mathrm{ml}$ 가 되 게 희석, 교반시킨 후 No. 1 filter paper로 여과 하였다. 여과한 액 $5 \mathrm{ml}$ 를 취하여 2-TBA시약 $(0.005 \mathrm{M}) 5 \mathrm{ml}$ 를 혼합한 후 실온 냉암소에서 15 시간 방치하고 $531 \mathrm{~nm}$ 에서 흡광도를 측정하 였으며, 계산은 TBA (malonaldehyde(MA) mg/ $1000 \mathrm{~g})=$ 흡광도 $\times 5.2$ 로 하였다. 
Table 1. Formula for nitrite-reduced sausages added Opuntia ficus indica pigment and sodium lactate

\begin{tabular}{lcccc}
\hline \multirow{2}{*}{ Ingredients } & \multicolumn{4}{c}{ Amount(\%) } \\
\cline { 2 - 5 } \multicolumn{1}{c}{ Meat } & $\mathrm{C}^{1)}$ & $\mathrm{T}^{2)}$ & $\mathrm{T}^{3)}$ & $\mathrm{T}^{4)}$ \\
\hline \hline Fat & 60 & 60 & 60 & 60 \\
Ice/Water & 20 & 20 & 20 & 20 \\
\hline Materials Total & 20 & 20 & 20 & 20 \\
\hline NPS (\%) & 100 & 100 & 100 & 100 \\
Betalain (\%) & 0.2 & 0.12 & 0.06 & 0.3 \\
Sodium lactate (\%) & 0 & 0.1 & 0.2 & 3 \\
Salt & 0 & 1 & 2 & 1.4 \\
\hline Spice Total & 1.2 & 1.28 & 3.6 & 4.7 \\
\hline Total & 1.4 & 2.5 & 103.6 & 104.7 \\
\hline
\end{tabular}

1) C, control(nitrite $100 \mathrm{ppm})$;

2) $\mathrm{T} 1$, treatment 1 (nitrite $60 \mathrm{ppm}+$ Opuntia ficus-indica pigment $0.1 \%+$ Sodium lactate $1 \%$ );

3) $\mathrm{T} 2$, treatment 2 (nitrite $30 \mathrm{ppm}+$ Opuntia ficus-indica pigment $0.2 \%+$ Sodium lactate $2 \%$ );

4) T3, treatment 3 (Opuntia ficus-indica pigment $0.3 \%$ + Sodium lactate $3 \%$ ).

5) NPS (salt $95 \%$ + nitrite $5 \%$ ).

\section{4. $\mathrm{pH}$ 측정 및 보수력 측정}

소시지의 $\mathrm{pH}$ 값은 $\mathrm{pH}$ meter (HANNA instruments, HI 8424)를 사용하여 소시지 표면에 임 의로 5 부분을 측정하여 평균치를 구하였다. 보 수력 측정은 가압여과지 면적법으로 시료 $2 \mathrm{~g}$ 을 여과지 (Whatman No. 2)에 놓고 $10 \mathrm{~kg} / \mathrm{cm}^{2}$ 의 압력으로 1 분간 가압 후, 여과지에 퍼진 수분 의 면적을 planimeter로 측정하였다.

계산식은 보수력 $(\%)=(\mathrm{A}-\mathrm{B}) / \times 100$ 으로 하 였으며, 이 때 $\mathrm{A}$ 는 여과지 전체면적, $\mathrm{B}$ 는 소시 지에 의하여 생성된 수분의 면적을 나타낸다.

\section{5. 총 세균수 측정}

제조한 각각의 소시지를 $3^{\circ} \mathrm{C}$ 에서 냉장 보관 하면서 1 주, 3 주 및 5 주에 걸쳐 균수를 다음과 같이 측정하였다. 각 시료 $10 \mathrm{~g}$ 을 멸균한 생리 식염수 $90 \mathrm{ml}$ 와 함께 stomacher (stomacher 400 Lab Blend, SEWARD, England)를 이용하여 2분
간 혼합하고 10 진 희석법으로 희석하여 각각을 Petrifilm $^{\mathrm{TM}}$ (3M Microbiology Products)에 접종하 고 $37^{\circ} \mathrm{C}$ 에서 $24 \sim 48 \mathrm{~h}$ 배양한 후 균수를 측정하 였다.

\section{6. 조직검사 및 관능검사}

검사를 위해 냉장보관중인 실험용 소시지를 실온에서 30 분 정도 방치한 후 약 $1.3 \mathrm{~cm}$ 의 높 이로 균일하게 자른 후 $500 \mathrm{~N}$ load cell을 이용 하여 2번 물림으로 원래 높이의 약 $75 \%$ 정도 가압하고, $500 \mathrm{~mm} / \mathrm{min}$ 의 cross-head speed와 100 $\mathrm{mm} / \mathrm{min}$ 의 chart speed로 조직감의 일차적인 특 징인 탄력성 (Springiness), 응집성 (Cohesiveness), 경도 (Hardness)와 씹힙성 (Chewiness), 검성(Gumminess), 부착성 (Adhesiveness) 등을 시료 당 10 회 반복 측정하여 그 평균값을 구하였다. 관능 검사는 훈련된 관능검사 요원 15 명을 선발하여 실시하였으며 외관, 색, 조직 및 향미에 대하여 각각 5점 척도법을 이용해 평가하였다. 


\section{7. 실험동물 사육 및 혈액 채취}

생후 5주(평균체중125 150g)된 Sprague-Dawley (SD)계 수컷 흰쥐 24마리를 코아텍 (Korea)에서 구입하여 실험시작 전 1주일간 적응시킨 후 체 중이 $170 \mathrm{~g}$ 내외인 쥐들을 체중에 따라 난괴법 (randomized complete block design)에 의해 6마 리씩 4군으로 분류하여 4주간 사육하였다. 물 은 자유급여 하였고, clean rack (신바이오텍사, Korea)에서 사육하였으며 소시지는 매일 동일 한 시간에 $40 \mathrm{~g}$ 으로 제한 급여하였다. 혈액은 하대정맥 및 심장에서 채취하였고 헤파린 처리 된 tube에 넣어 ice bath에 20분간 방치한 후 $3,000 \mathrm{rpm}$ 에서 15 분간 원심 분리하여 혈장을 분 리하여 녹십자에 분석을 의뢰하였다.

\section{8. 증체량 및 혈당측정}

증체량은 1 주일 간격으로 측정 전 2 시간 절 식 후 체중을 측정하였으며, 혈당측정은 급여 28 일째에 실험동물을 12 시간 절식시킨 후 꼬리 정맥에서 채혈하여 공복 시 혈당수준을 측정한 후, 다시 sausage를 급여하고 120 분 뒤에 꼬리 정맥으로부터 채혈하여 혈당계 (Onetouch Ultra ${ }^{\mathrm{TM}}$, Lifescan, Korea)로 측정하였다.

\section{9. 통계처리}

모든 자료는 SAS (1996)의 General Linear Model procedure를 이용하여 Duncan's multiple range test(Duncan, 1995)로 처리하여 평균간의 유의성을 검정하였고, ANOVA 방법으로 분석 을 하였다.

\section{III. 결과 및 고찰}

\section{1. 색도}

Table 2에서 보는 바와 같이 $\mathrm{L} *$ 값 (명도)은 아질산나트륨 농도가 높은 대조구에서 낮은 농 도의 처리구 순으로 낮아지는 경향을 보여주고 있다 $(\mathrm{P}<0.05)$. 그러나 아질산나트륨을 전혀 첨 가하지 않은 처리구 (T3)라 할지라도 약간 높게 나타났다. 이는 손바닥선인장 색소의 영향으로 생각되는데, 강과 이 (2003)에 의하면 저 농도의 아질산염 소시지에서 인산염이나 레드비트 색 소를 첨가하였을 경우 $\mathrm{L} *$ 값이 높아진 결과를 보였다. $\mathrm{a}^{*}$ 값 (적색도)의 경우 아질산나트륨의 첨가량을 $100 \mathrm{ppm}$ 에서 $60 \mathrm{ppm}$ 및 $30 \mathrm{ppm}$ 으로 줄여도 낮아지지 않고 오히려 $30 \mathrm{ppm}+0.2 \%$ 손바닥선인장 첨가구 (T2)에서 높은 경향을 보 여 주었다. 그러나 아질산나트륨을 첨가하지 않은 처리구 (T3)에서는 유의적으로 적색도가 가장 낮은 수치를 나타내어 $(\mathrm{P}<0.05)$, 손바닥 선 인장에 의한 아질산염 저감화 가능성은 있는 것으로 나타났으나, 아질산나트륨 비 첨가의 경우 적색도를 충분히 발현시킬 수 없어 아질 산나트륨의 농도를 최소화하여 병행 사용하는 것이 필요한 것으로 나타났다.

$\mathrm{b}$ *값(황색도)의 경우는 천연색소인 선인장색

Table 2. Effects of Opuntia ficus-indica pigment and sodium lactate on color of nitritereduced sausages

\begin{tabular}{cccccc}
\hline \multirow{2}{*}{ Parameters } & \multicolumn{5}{c}{ Treatments } \\
\cline { 2 - 5 } & $\mathrm{C}^{1)}$ & $\mathrm{T}^{2)}$ & \multicolumn{1}{c}{$2^{3)}$} & $\mathrm{T3}^{4)}$ & $\mathrm{SEM}^{5)}$ \\
\hline \hline $\mathrm{L}^{* 6)}$ & $73.65^{\mathrm{a}}$ & $70.81^{\mathrm{b}}$ & $68.91^{\mathrm{c}}$ & $70.58^{\mathrm{b}}$ & 0.01 \\
$\mathrm{a}^{* 7)}$ & $9.41^{\mathrm{ab}}$ & $9.23^{\mathrm{b}}$ & $9.53^{\mathrm{a}}$ & $6.08^{\mathrm{c}}$ & 0.07 \\
$\mathrm{~b}^{* 8)}$ & $5.70^{\mathrm{d}}$ & $9.41^{\mathrm{c}}$ & $11.50^{\mathrm{b}}$ & $13.74^{\mathrm{a}}$ & 0.12 \\
\hline
\end{tabular}

1)-4) Abbreviation is the same as Table 1.

5) Pooled standard error of mean.

6) L*: Lightness; 7) $\mathrm{a}^{*}$ : Redness; ${ }^{8)} \mathrm{b}^{*}$ : Yellowness.

${ }^{a-d}$ Means with same row having same superscript are not significantly different $(\mathrm{p}>0.05)$. 
소를 많이 첨가할수록 유의적으로 황색도가 높 게 나타났다 $(\mathrm{P}<0.05)$. 이는 황색색소인 베타케로 틴 함량이 많은 우육이 $b^{*}$ 값이 높았다는 결과 (Yang 등, 1999)로부터도 알 수 있듯이 천연색소 의 첨가는 $\mathrm{b}^{*}$ 값을 높이는 것으로 판단된다.

\section{2. 산패도}

Fig. 1에서 보는 바와 같이 처리구에 비해 아 질산나트륨 함량이 높은 대조구에서 TBA 값이 유의적으로 낮게 측정되었다 $(\mathrm{P}<0.05)$. 각 처리 구간에도 아질산나트륨의 함량이 높을수록 소 시지의 TBA 값은 낮게 나타났다 $(\mathrm{P}>0.05)$. 손바 닥선인장색소 (김 등, 1995: 이 등, 1999) 및 유 산나트륨의 항산화 효과(Choi와 Chin, 2003)도 잘 알려져 있으나, 본 실험 결과 아질산나트륨 에 비해 항산화 효과는 약한 것으로 판단되었 다.

\section{3. $\mathrm{pH}$ 와 보수력}

일반적으로 단백질의 등전 $\mathrm{pH}$ 에서는 보수력 이 나쁘지만, $\mathrm{pH}$ 가 높거나 낮으면 보수력은 향 상된다. 그러나, 낮은 $\mathrm{pH}$ 보다는 높은 $\mathrm{pH}$ 에서 보수력은 더욱 높게 나타난다는 사실은 잘 알 려져 있다.

$\mathrm{pH}$ 변화는 Table 3에서 보는 바와 같이 아질 산나트륨 함량에 관계없이 처리구간에 거의 나 타나지 않았으며, 유산나트륨의 처리구간에도 거의 변화를 보이지 않았다. 이는 저지방 frankfurter 제조시 유산나트륨 $60 \%$ 용액을 3\%

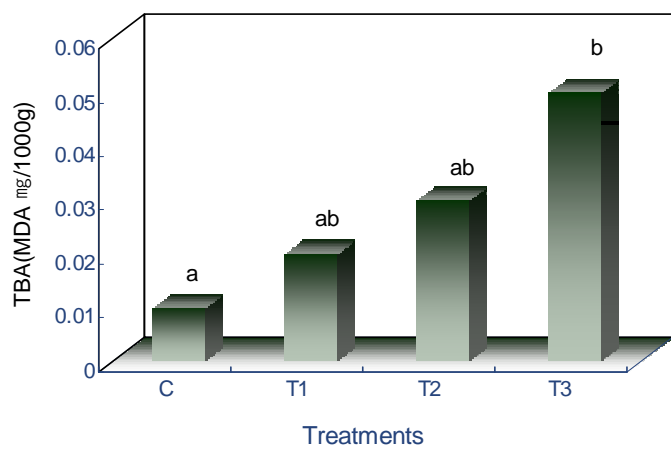

Fig. 1. Effect of Opuntia ficus-indica pigment and sodium lactate on TBA of nitritereduced sausages.

1)-4) Abbreviation is the same as Table 1 .

a-d Means with same row having same superscript are not significantly different $(\mathrm{p}>0.05)$.

까지 첨가하였을 때 $\mathrm{pH}$ 변화에는 차이가 없었 다고 한 Bloukas 등 (1977)의 결과와 유사하였 다. 그러나 아질산나트륨 비 첨가(T3)구에서 유 의적인 차이는 없으나 약간 증가하는 경향을 보여 레드비트 색소 첨가 시와 유사한 결과를 보였다 (강과 이, 2003).

보수력은 아질산나트륨 첨가의 대조구가 처 리구에 비해 높게 나타났으나, 처리구간에는 아질산 함량을 줄일지라도 손바닥선인장 색소 의 첨가량에 따라 향상되는 경향을 보였으며, 이 또한 강과 이 (2003) 결과와 유사하였다.

\section{4. 총 세균수}

제조된 소시지를 냉장 저장하면서 5주간의

Table 3. Effect of Opuntia ficus-indica pigment and sodium lactate on $\mathrm{pH}, \mathrm{WHC}$ of nitritereduced sausage

\begin{tabular}{cccccc}
\hline \multirow{2}{*}{ Parameters } & \multicolumn{5}{c}{ Treatments } \\
\cline { 2 - 5 } & $\mathrm{C}^{1)}$ & $\mathrm{T1}^{2)}$ & $\mathrm{T}^{3)}$ & $\mathrm{T3}^{4)}$ & $\mathrm{SEM}^{5)}$ \\
\hline \hline $\mathrm{pH}$ & $5.53^{\mathrm{a}}$ & $5.53^{\mathrm{a}}$ & $5.53^{\mathrm{a}}$ & $5.63^{\mathrm{a}}$ & 0.09 \\
$\mathrm{WHC}^{6)}$ & $66.06^{\mathrm{a}}$ & $59.51^{\mathrm{b}}$ & $62.99^{\mathrm{ab}}$ & $62.10^{\mathrm{ab}}$ & 1.34 \\
\hline
\end{tabular}

\footnotetext{
1)-4) Abbreviation is the same as Table 1.

5) Pooled standard error of mean.

6) WHC: Water holding capacity.

a-b Means with same row having same superscript are not significantly different ( $>>0.05)$.
} 
생균수를 측정한 결과는 Fig. 2와 같다. 3주간 의 냉장저장에서는 대조구에 비해 처리구 $\mathrm{T} 1$, $\mathrm{T} 2$ 가 총세균수가 많게 나타났다. 이는 아질산 나트륨의 첨가량이 적고, 유산나트륨의 첨가량 이 적었기 때문으로 사료된다. 그러나 냉장저 장 5주간에서는 아질산나트륨을 첨가하지 않았 을지라도 유산나트륨의 첨가량이 높은 $\mathrm{T} 3$ 구가 에서 적게 나타났다. 이는 저장성에 관한한 유 산나트륨의 항 미생물 효과 및 아질산나트륨의 대체효과가 있다는 보고와 잘 일치하고 있다 (Choi와 Chin, 2003; Choi 등, 2003).

유산나트륨은 병원성 미생물의 성장을 억제 시켜 저장성을 증진시킬 뿐만 아니라 향미를 개선시키는 특징을 가지고 있기 때문에 식육제 품에서 저장성과 관련하여 유용하게 사용되고 있다(Choi 등, 2003). 유산나트륨을 1.5 3.5\% 첨가시 계육과 칠면조육에서 Cl. botulinum 성 장이 억제되는 것이 보고된 바 있으며 (Mass 등, 1989), 유산나트륨의 증식억제 효과는 특히 Listeria monocytogenesis에게 작용하여 식육 가 공품의 저장성을 높이는데 효과적인 것으로 알 려져 있다 (Shelef와 Yang, 1999).

\section{5. 조직감 및 관능검사}

조직감은 식품의 구조를 이루고 있는 원소들

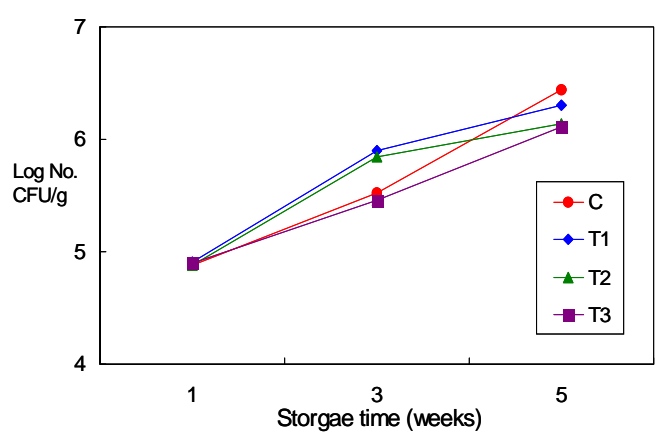

Fig. 2. Effect of Opuntia ficus-indica pigment and sodium lactate on changes of total plate counts (CFU/g) of nitritereduced sausages during storage at $3^{\circ} \mathrm{C}$.

1)-4) Abbreviation is the same as Table 1.

의 복합체가 생리적인 감각을 통하여 느껴지는 것으로 식습관, 소비자의 성향, 제조공정, 치아 의 건강에 영향을 받는 식품의 중요한 특성이 다. Table 4에서 탄성 (Springiness)은 대조구에서 유의적으로 높게 평가 되었으나, 탄성 (Springiness)을 제외한 모든 조직감(물성)은 처리구간 에 유의적 차이는 보이지 않았다. 그러나 대조 구에서 경도(Hardness), 검성 (Gumminess)이 낮 게 나타났다 $(\mathrm{P}>0.05)$. 탄성이 높고, 경도 및 검 성이 낮은 것은 보수력 (Table 3)이 높은 것과

Table 4. Effect of Opuntia ficus-indica pigment and sodium lactate on texture analysis of nitrite-reduced sausages

\begin{tabular}{lrrrrr}
\hline \multirow{2}{*}{ Parameters } & \multicolumn{5}{c}{ Treatments } \\
\cline { 2 - 6 } & \multicolumn{1}{c}{$\mathrm{C}^{1)}$} & \multicolumn{1}{c}{$\mathrm{T}^{2)}$} & \multicolumn{1}{c}{$\mathrm{T}^{3)}$} & $\mathrm{T}^{4)}$ & $\mathrm{SEM}^{5)}$ \\
\hline \hline Springiness & $0.96^{\mathrm{a}}$ & $0.90^{\mathrm{b}}$ & $0.92^{\mathrm{ab}}$ & $0.94^{\mathrm{ab}}$ & 0.01 \\
Cohesiveness & 0.59 & 0.59 & 0.59 & 0.60 & 0.01 \\
Chewiness & 736.96 & 769.55 & 789.43 & 792.62 & 40.34 \\
Hardness & 1303.94 & 1450.12 & 1449.32 & 1416.52 & 61.77 \\
Gumminess & 769.50 & 853.90 & 858.77 & 843.24 & 35.99 \\
Adhesiveness & 37.17 & 20.12 & 23.96 & 28.45 & 5.36 \\
\hline
\end{tabular}

1)-4) Abbreviation is the same as Table 1.

5) Pooled standard error of mean..

${ }^{a-b}$ Means with same row having same superscript are not significantly different $(p>0.05)$. 
관련이 있는 것으로 생각된다. 즉, 보수력이 나 쁜 PSE (pale, soft, exudative) 돈육이 탄성이 떨 어지는 것과 같다고 할 수 있다. 또한 보수력 이 높으면 연도가 증가할 수 있다. 따라서 탄 성이 높은 대조구에서 경도 및 검성이 낮게 나 타난 것으로 추측된다. 진과 최 (2001)는 유산나 트륨의 함량이 증가함에 따라 부서짐성, 경도, 검성과 저작성이 높아진다고 보고하였는데 본 실험결과와도 유사한 결과라 생각된다.

Table 5에서 보는 바와 같이 관능검사에 의 한 외관 및 색상은 아질산나트륨을 첨가한 대 조구가 좋은 평점을 보였고, 조직 및 풍미에는 처리구에서 각각 좋은 평점을 받았다 $(\mathrm{P}>0.05)$. 특히 아질산나트륨을 첨가하지 않은 $\mathrm{T} 3$ 에서 비 교적 높은 평점은 조직 및 풍미의 관점에서는 별 문제가 되지 않음을 시사하고 있다.

\section{6. 증체량 및 혈액성상}

실험동물 쥐의 증체효과 (Table 6)는 대조구 와 처리구간에 큰 차이는 거의 없었다 $(\mathrm{P}>0.05)$. 쥐의 혈당 (Table 7)은 사료급여 전에는 대조구 와 처리구간에 유의적인 차이가 없었으나, 급 여 후에는 $\mathrm{T} 1$ 에서 유의적으로 높게 나타났다 $(\mathrm{P}<0.05)$. 그러나 신 (2003) 등의 보고에 의하면 손바닥선인장 열매 및 줄기 추출물은 혈당을 낮춘다고 하였으나, 본 실험결과는 유의적인 차이를 보이지 않았다.

총콜레스테롤, HDL-, LDL-콜레스테롤 및 중 성지방 (Table 8)은 모두 대조구보다 처리구에 서 유의적으로 낮은 수치를 보였다 $(\mathrm{P}<0.05)$. 이 러한 결과는 유산나트륨 및 선인장 색소의 작 용으로 생각된다 (Fernandez 등, 1992). 또한 최 (2002a,b) 등이 보고한 식이성 및 알콜성 고지 혈증에 선인장 추출물이 효과적이었다는 보고 와 일치하고 있다. 특히 총콜레스테롤인 경우 는 처리구중에서 $\mathrm{T} 2$ 가 가장 낮은 수치를 보이 고 있는데, 좋은 콜레스테롤로 알려지고 있는

Table 5. Effect of Opuntia ficus-indica pigment and sodium lactate on sensory evaluation of nitrite-reduced sausages

\begin{tabular}{lccccc}
\hline \multirow{2}{*}{ Parameters } & \multicolumn{5}{c}{ Treatments } \\
\cline { 2 - 6 } & $\mathrm{C}^{1)}$ & $\mathrm{T}^{2)}$ & $\mathrm{T}^{3)}$ & $\mathrm{T}^{4)}$ & $\mathrm{SEM}^{5)}$ \\
\hline \hline Appearance & $3.60^{\mathrm{a}}$ & $3.20^{\mathrm{b}}$ & $3.25^{\mathrm{ab}}$ & $3.45^{\mathrm{ab}}$ & 0.12 \\
Color & $3.60^{\mathrm{a}}$ & $3.13^{\mathrm{b}}$ & $3.35^{\mathrm{ab}}$ & $3.45^{\mathrm{ab}}$ & 0.15 \\
Texture & $2.48^{\mathrm{b}}$ & $2.70^{\mathrm{ab}}$ & $2.68^{\mathrm{ab}}$ & $3.00^{\mathrm{a}}$ & 0.15 \\
Flavor & $2.92^{\mathrm{b}}$ & $3.06^{\mathrm{ab}}$ & $3.36^{\mathrm{a}}$ & $3.38^{\mathrm{a}}$ & 0.13 \\
\hline
\end{tabular}

1)-4) Abbreviation is the same as Table 1.

5) Pooled standard error of mean.

a-b Means with same row having same superscript are not significantly different $(\mathrm{p}>0.05)$.

Table 6. Effect of feeding nitrite-reduced sausages added Opuntia ficus-indica pigment and sodium lactate on body weight gain of rat

\begin{tabular}{cccccc}
\hline \multirow{2}{*}{ Parameters } & \multicolumn{5}{c}{ Treatments } \\
\cline { 2 - 5 } & $\mathrm{C}^{1)}$ & $\mathrm{T}^{2)}$ & $\mathrm{T}^{3)}$ & $\mathrm{T}^{4)}$ & $\mathrm{SEM}^{4)}$ \\
\hline \hline Body weight gain. & $56.67^{\mathrm{a}}$ & $53.17^{\mathrm{a}}$ & $51.33^{\mathrm{a}}$ & $51.33^{\mathrm{a}}$ & 5.76 \\
\hline
\end{tabular}

\footnotetext{
1)-4) Abbreviation is the same as Table 1.

5) Pooled standard error of mean.

${ }^{a-c}$ Means with same row having same superscript are not significantly different $(p>0.05)$.
} 
Table 7. Effect of feeding nitrite-reduced sausages added Opuntia ficus-indica pigment and sodium lactate on blood glucose of rat

\begin{tabular}{lrrrrr}
\hline \multirow{2}{*}{ Parameters } & \multicolumn{5}{c}{ Treatments } \\
\cline { 2 - 6 } & \multicolumn{1}{c}{$\mathrm{C}^{1)}$} & \multicolumn{1}{c}{$\mathrm{T}^{2)}$} & \multicolumn{1}{c}{$2^{3)}$} & \multicolumn{1}{c}{$3^{4)}$} & $\mathrm{SEM}^{5)}$ \\
\hline \hline Pre-Feeding & $91.17^{\mathrm{a}}$ & $98.17^{\mathrm{a}}$ & $90.50^{\mathrm{a}}$ & $103.50^{\mathrm{a}}$ & 10.25 \\
Post-Feeding & $139.67^{\mathrm{b}}$ & $223.33^{\mathrm{a}}$ & $133.33^{\mathrm{b}}$ & $168.83^{\mathrm{b}}$ & 14.96 \\
\hline
\end{tabular}

1)-4) Abbreviation is the same as Table 1.

5) Pooled standard error of mean.

a-b Means with same row having same superscript are not significantly different $(p>0.05)$.

Table 8. Effect of feeding nitrite and nitrite-reduced sausages added Opuntia ficus-indica pigment and sodium lactate on total cholesterol (TC), HDL, and LDL- cholesterol and triglyceride $(\mathrm{TG})$ concentration of plasma in rat

\begin{tabular}{lccccc}
\hline \multirow{2}{*}{ Parameters } & \multicolumn{5}{c}{ Treatments } \\
\cline { 2 - 5 } & $\mathrm{C}^{1)}$ & $\mathrm{T}^{2)}$ & $\mathrm{T}^{3)}$ & $\mathrm{T}^{4)}$ & $\mathrm{SEM}^{5)}$ \\
\hline \hline TC & $92.00^{\mathrm{a}}$ & $74.33^{\mathrm{b}}$ & $55.67^{\mathrm{c}}$ & $72.67^{\mathrm{b}}$ & 4.14 \\
H.D.L & $29.33^{\mathrm{a}}$ & $4.67^{\mathrm{b}}$ & $3.00^{\mathrm{b}}$ & $5.33^{\mathrm{b}}$ & 0.84 \\
L.D.L & $18.67^{\mathrm{ab}}$ & $20.00^{\mathrm{a}}$ & $12.33^{\mathrm{b}}$ & $15.33^{\mathrm{ab}}$ & 1.94 \\
TG & $124.33^{\mathrm{a}}$ & $72.00^{\mathrm{b}}$ & $72.33^{\mathrm{b}}$ & $73.67^{\mathrm{b}}$ & 5.22 \\
\hline
\end{tabular}

1)-4) Abbreviation is the same as Table 1.

5) Pooled standard error of mean.

a-b Means with same row having same superscript are not significantly different $(p>0.05)$.

$\mathrm{HDL}$ 인 경우 처리구에서 낮은 수치를 보인 점 은 이에 대한 보완 연구가 필요할 것으로 나타 났다.

$$
\text { IV. 요 약 }
$$

본 연구에서는 천연 손바닥선인장 색소 및 유산나트륨이 저 아질산나트륨 소시지에 미치 는 영향을 조사함으로서 아질산염을 부분 대체 (저감화)하고자 소시지를 제조하여 그 가능성을 검토하였고 천연 폴리페놀이 함유된 손바닥선 인장 추출 색소 첨가에 따른 소시지의 혈액 특 성을 확인하기 위해 동물실험을 실시하였으며 결과는 다음과 같다.

대조구와 처리구간에 유의적인 차이를 보이
지 않은 항목은 소시지의 적색도 $\left(\mathrm{a}^{*}\right)$, 총세균 수, $\mathrm{pH}$, 보수력, 조직분석, 관능검사, 쥐의 증체 량 및 혈당이었으나, 대조구와 처리구간에 유 의적인 차이를 보인 항목은 $\mathrm{TBA}$ 와 혈액 중의 콜레스테롤 (total, LDL, HDL) 및 중성지방이었 다. 즉 $\mathrm{TBA}$ 값은 대조구에서, 콜레스테롤 및 중성지방은 처리구에서 각각 낮은 수치를 보였 다 $(\mathrm{P}<0.05)$. 그러나 처리구 중에서는 $\mathrm{T} 2$ (30 ppm of nitrite $+2 \%$ of sodium lactate $+0.2 \%$ Opuntia ficus indica pigment)가 가장 효과적인 것으로 나타났다.

결론적으로 $30 \mathrm{ppm}$ 의 아질산나트륨, $2 \%$ 의 유산나트륨, $0.2 \%$ 의 손바닥선인장 색소의 혼합 사용은 아질산나트륨의 통상 첨가량 $100 \mathrm{ppm}$ (잔존량 $70 \mathrm{ppm}$ 이하)을 $30 \mathrm{ppm}$ 으로 줄여도 발 
색, 저장성 및 풍미에는 별문제가 없이 사용 가능한 것으로 나타났으며, 동시에 혈중콜레스 테롤 및 중성지방이 감소하는 효과도 가질 수 있다고 사료되었다.

$$
\mathrm{V} \text {. 사 사 }
$$

이 연구는 2006학년도 단국대학교 대학연구 비 지원에 의해 연구된 것으로 이에 감사드립 니다. 본 연구에 많은 도움을 주신 지오푸드텍 의 정승희 박사님께도 감사의 뜻을 표하는 바 입니다.

\section{VI. 인 용 문 헌}

1. Bloukas, J. G., Paneras, E. D. and Foumitzis, G. C. 1997. Sodium lactate protective culture effects on quality characteristics and shelf-life of low-fat frankfurters produced with olive oil. Meat Sci. 45(2):223-238.

2. Chin, K. B., Oh, M. Y. and Park, S. Y. 2006. Animal products and processing: Evaluation of high molecular weight of chitosan as a replacer of sodium nitrite on the physico-chemical properties and microbial changes of low-fat sausages during refrigerated storage. J. Anim. Sci. Technol. 48: 563-574.

3. Choi, S. H. and Chin, K. B. 2003. Evaluation of sodium lactate as replacement for the conventional chemical preservatives in comminuted sausages inoculated with Listeria monocytogenes. Meat Sci. 65:531-537.

4. Choi, S. H., Kim, K. H., Eun, J. B. and Chin, K. B. 2003. Growth suppression of inoculated Listeria monocytogenes and physicochemical and textural properties of low-fat sausages as affected by sodium lactate and a fat replacer. J. Food Sci. 68:2542-2546.

5. Fernandez, M. L., Lin, E. C. K., Trejo, A. and McNamara, D. J. 1992. Prickly pear (Opuntia sp)pectin reverses low density lipoprotein receptor suppression induced by a hypercholesterolemic diat in guinea pigs. J. Nutr. 122:2330-2339.

6. Mass, M. R., Glass, K. A. and Doyle, M. P. 1989. Sodium lactate delays toxin production by Clostridium botulinum in cook-in-bag turkey products. Appl. Environ. Microbiol. 55:2226-2229.

7. Massey, R. C., Crews, C., Davies, R. and McWeeny, D. J. 1978. A study of the competitive nitrosations of pyrrolidine, ascorbic acid, cysteine and p-cresol in a protein-base model system. J. Sci. Food Agric. 29:815-821.

8. O’Boyle, A., Rubin, L. J., Diosady, L. L., Aladin-Kassam, N., Comer, F. and Brightwell, W. 1990. A nitrite-free meat curing system and its application to the production of wieners. Food Tchnol. 44:88-104.

9. SAS. 1996. SAS user guide. Release 6.12 edition. SAS Inst Inc Cary NC. USA.

10. Shelef, L. and Yang, Q. 1999. Growth suppression of Listeria monocytogenes by lactate in broth, chicken and beef. J. Food Prot. 54:283-287.

11. Sofos, J. N., Busta, F. F. and Allen, C. E. 1980. Influence of $\mathrm{pH}$ on Clostridium botulinum control by sodium nitrite and sorbic acid in chicken emulsions. J. Food Sci. 45:7-12.

12. Yang, A., Larsen, T. W., Powell, V. H. and Tume, R. K. 1999. A comparison of fat composition of Japanese and long-term gained fat Australian steers. Meat Sci. 51:1-9.

13. 강종옥, 이강현. 2003. 레드비트 색소 및 키토산 첨가가 저 아질산염 소시지에 미치는 효과. 한국 축산식품학회지. 23(3):215-220.

14. 강종옥, 박종열, 김철현. 2001. 흑향미로부터 추 출된 식용 발색제. 한국특허 0294654.

15. 국성호, 최순희, 강상미, 박성용, 진구복. 2003. 젖산나트륨과 키토산을 첨가한 저지방 기능성 소시지의 냉장 저장 중의 품질 및 저장성 증진 효과. 한국축산식품학회지. 23(2):128-136.

16. 김인환, 김명희, 김홍만, 김영언. 1995. 선인장열 매 색소의 열 안정성에 대한 항산 화제의 효과. 한국식품과학회지. 27(6):1013-1016.

17. 류미라, 김은영, 정경숙. 2003. 홍국 첨가가 소시 지 품질특성에 미치는 영향. 한국식품과학회지. 
35(2):229-234.

18. 신지은, 한명주, 이인경, 문영인, 김동현. 2003. Alloxan 및 Streptozotocin 유도 당뇨모델 동물에 서 손바닥 선인장의 혈당강하 효과. 생약학회지. 34(1):75-79.

19. 윤선경, 박선미, 김연주, 안동현. 2001. 돈육 소시 지에 첨가한 키토산의 아질산염 대체 효과에 관 한 연구. 한국식품과학회지. 33(5):551-559.

20. 이영철, 신경아, 정승원, 문영인, 김성대, 한용남. 1999. 손바닥 선인장 분말을 첨가한 생면의 품질 특성. 한국식품과학회지. 31(6):1604-1612.

21. 진구복, 최순희. 2001. 젖산나트륨과 지방대체제 의 첨가가 냉장저장 중 저지방 볼로나 소시지의
품질 및 저장성에 미치는 영향. 한국식품영양과 학회지. 30(5):858-864.

22. 최종원, 이정규, 이영철, 문영인, 박희준, 한용남. 2002a. 손바닥선인장 열매 및 줄기 추출물의 생 리활성 (II)-흰쥐의 식이성 고지혈증에 미치는 영향. 생약학회지. 33(3):230-237.

23. 최종원, 이정규, 문영인, 박희준, 한용남. 2002b. 손바닥선인장 열매 및 줄기 추출물의 생리활성 (III)-흰쥐의 알코올성 고지혈증에 미치는 영향. 생약학회지. 33(3):238-244.

(접수일자 : 2008. 7. 8. / 수정일자 : 2008. 8. 1./ 채택일자 : 2008. 8. 12.) 